\title{
Patterns of Public Policy from the Perspective of Local Government Mandatory Affairs Implementation
}

\author{
Muhamad Nur Afandi \\ Sekolah Tinggi Ilmu Administrasi, Lembaga Administrasi Negara (STIA LAN) \\ Bandung, Indonesia \\ m.n.afandi@gmail.com
}

\begin{abstract}
Local Government Law(Law 23/2014) has mandated some government affairs to the provincial and local government. It consists of absolute, concurrent and general affairs. The concurrent government affair consists of compulsory and optional local government affairs. The aim of the research is to find out the good elements of forming the local compulsory government affairs and the pattern of correlation between those elements. And how the creation of a system of public policy (technological measures) relating to the Mandatory Regional Affairs in the Government of Ciamis District. This research methodology uses a qualitative approach, in which the corelation of forming elements in the compulsory affairs is assessed using correlation approach (corelation pattern) to determine the structure of the implementation of local compulsory government affairs. It uses study of primary and secondary documents plus interviews with respondents. The study found that the Ciamis District Government has implemented a whole of government issues regional. Efforts to create a system of public policy relating to the affairs of the regions in Ciamis in improving performance achievements can be done through capacity building and human resource capabilities and cultural transformation apparatus.
\end{abstract}

Keywords - public policy, implementation, compulsory local government affairs

\section{INTRODUCTION}

Local government affairs, as Law No. 23, 2014 has mandated the government administration in multiple areas of government affairs. In government affairs is interpreted as the power of provincial and district local governments used to protect, serve, empower and provide social welfare in the territory of his government. It consists of government absolute, concurrent and general affairs. Concurrent administration affairs shall consist of government affairs area and selection area. Mandatory government affairs area is related to basic services and are not related to basic services. Mandatory government affairs area is related to basic services and are not related to basic services.

There are six areas relating to compulsory service area for basic services, and eighteen matters not related to basic services. Ciamis District Government as one of the district that are within the scope of local government of West Java province has a duty to carry out orders this law in terms of compulsory service area. Compulsory service district both with regard to basic services or matters not related to basic services.

Compulsory service region is a policy that must be taken. The form is a program created for the purpose, values and practice / concerted action [1]. The program can be interpreted as a document of local development plans. Implements development programs are divided into time periods set forth in the long-term development plan of the area, medium term development plans and short-term development plan. The subject matter of this research is to identify at which level of Ciamis District Government may exercise this affairs, and to what degree of coherence between obligatory and RPJMD of Kab. Ciamis.

The purpose of the research is to find out the good elements forming the mandatory government affairs of the districts and the pattern of correlation between forming elements such affairs. Affairs of district governments will be focused on matters relating to basic services. And how to create a system of public policy (technological measures) relating to the affairs of the regions in Ciamis District Government. The limitation of this study is that the pattern of public policy question here will be viewed from the perspective of implementation of obligatory districts based on the implementation of RPJMD Ciamis district government in the period 2009-2014. In the implementation of regional government affairs division needs to pay attention to potential areas. Distribution of affairs which does not consider the ability of blood has the potential to harm the interests pulbik [2].

\section{CONCEPT OF PUBLIC POLICY}

Policies can be seen as a philosophical concept, as a product, as a process and as a framework [3]. Local Government in implementing a policy to be able to respond to the problems faced by taking into account the resources owned by the government, both central and local government. Policies theory underlying this policy is used in the affairs of both central and local government. In general, the policy cycle covers the formulation, implementation and evaluation [4]. The existence of public policy is very important in local government affairs because its existence is crucial to achieve a goal to be desired. Government affairs consisting of 
Compulsory affairs regarding the functional divisions between central and local governments is a program that should be run by the local government, then in this case the policy is an elements of the program and the decisions [5]. The programs that have been determined accompanied by the proper implementation of government affairs where that need to be implemented both at the central (national), as well as provincial and district / city.

Meaning of public policy is a series of actions that have specific objectives and implemented by a group of actors in order to solve a particular problem. Implementation of programs in implementing the obligatory functions of local government areas in the part of the public policy set forth in the policies of the region carried out by the region through local legislation. Programs and activities implemented by the local device is a part of regional policies in order to achieve the goals and objectives of local government that has been agreed in the regional development plans.

\section{IMPLEMENTATION OF LOCAL GOVERNMENT AFFAIRS WITHIN THE FRAMEWORK OF REGIONAL AUTONOMY}

In the implementation of the policy was essentially directed at achieving the goals and objectives that have been set [6]. Implementation is part of a policy whereby the stages in the policy process one of which is how you can implement policies that have been planned to run well. Implementation of affairs of the regions as in Law No. 23, 2014 that the government affairs konkruen consists of obligatory and selection matters. Where the existence of the difference between the provincial government and district / city is in terms of regional or local, in this case it is often known Autonomy. The implementation of regional autonomy resulted in the autonomous region which has a unit of community boundaries authorized to regulate and manage government and public interests at its own initiative based on the aspirations of the people in the system of the Republic of Indonesia [7]. Hope the end of the implementation of regional autonomy, regional governments capable of prospering communities through programs that have been set.

Government implementation in areas relating to the affairs of the regions as outlined in the regional development plans, it is necessary to pay attention to the existing policy in order to air the coherence between the central and regional policies as outlined in the development plan document. Synergy between the development plans related to the medium-term development plan with the plans of local governments is very important that development programs can be run properly.

\section{THE SYSTEMS APPROACH IN PUBLIC POLICY PERSPECTIVE}

In essence, that the implementation process is an interrelated system, because it is part of the implementation of the stages in the policy process in running both central and local government. The system is a phenomenon that has defined its structure [8]. It conveys the message that all the elements forming the system and the corresponding relationships between systems being undefined between system and environment of a relationship interplay. This system theory that explains the constituent elements of policies related to government affairs of the regions. The theory of the system will also note the correlation between its constituent elements, so that the overall picture of the structure in the form of public policy of this pattern can be determined by either. After an overview of the structure of public policy is known, the next step is the creation of a system (or the necessary technological measures) relating to public policy. . the notion of public policy may mean that public policies are those policies developed by governmental bodies and officials [9]. Each course has a goal of public policy, and public policy is always guided by the legislation.

Creation of system of public policy beriakitan government affairs shall be held by the District Government of Ciamis used as an instrument in the context of local government is able to increase revenue. Local revenues have an important role for local government in the framework of the welfare society.

\section{RESEARCH METHODOLOGY}

Methodology of this study uses a qualitative research approach, where relationship forming elements in the obligatory assessed using correlation approach (pattern relation) to determine the structure of the implementation of mandatory government affairs district. Study of primary and secondary documents plus interviews with respondents related to the method used in this study.

\section{RESEARCH RESULT}

The study shows that the Ciamis District Government has implemented a whole obligatory as many as 26 matters pertaining to basic services and not basic services. As for the influence ciamis district governments have implemented mandatory whole affair, it has mengindikasikasikan that the elements of the area has been able to run local programs, so that the program can be achieved Ciamis regency development well, which deals with compulsory urursan local area. As for the institutional aspects of implementing compulsory affairs is distributed into 29 (twenty nine) working unit (SKPD). There are some obligatory functions carried out more than 1 (one) device area. The determination of the number of devices in Ciamis region is based on the needs of the region based on the analysis of local government institutions Ciamis District. the strategic plans of each SKPD in the implementation of governmental affairs shall Ciamis Regency has accommodated well in the Medium Term Development Plan (RPJMD). It is based on the results of the correlation between elements within RPJMD associated with elements of each of the Strategic Plan (Plan) SKPD. Thus the preparation of a strategic plan has been referred to RPJMD Ciamis District Thus the preparation of a strategic plan has been referred to RPJMD Ciamis District.

Checking how the implementation of the sector plans in Ciamis regency done by reviewing Government Agencies Performance Accountability Report (LAKIP) 2014. LAKIP is a form of accountability for the achievement of strategic 
objectives for the financial year 2014. Ciamis District Government Performance measurement is done by collecting performance data from each SKPD designated as the responsible provider performance data based on the objectives to be achieved, and other relevant agencies such as the Central Statistics Agency (BPS), etc.

Local Government Performance measurement of Ciamis district conducted against 32 targets using 135 indicators set forth in the Stipulation of Performance 2014. Of the 135 indicators measured, 83 indicators $(61.48 \%)$ reached or exceeded the target, as many as 15 indicators $(11.11 \%)$ did not reach the target, but there is an increase compared with last year's results, and as many as 37 indicators (22.41 .\%) did not reach the target. This has an impact on the realization of the budget for development programs in Ciamis District Local Government has not achieved optimally. Efforts to improve the achievement of targets and can be implemented in an optimal one needs to optimize the role of supervision and control of development programs by the local device

\section{CONCLUSIONS}

Based on the analysis conducted above it is concluded to be grouped into two as follows:

1) Forming elements obligatory Ciamis regency and pattern of correlation between these elements is:

- Ciamis District Government has implemented a whole obligatory as many as 26 (twenty-six), distributed into 29 (twenty nine) working unit (SKPD).

- Overall obligatory functions have been accommodated well in the Medium Term Development Plan (RPJMD), this is based on the results of the correlation between the elements contained in RPJMD associated with elements of each of the Strategic Plan (Plan) of each SKPD.

- Program priorities contained in its medium as much as 32 strategic objectives set out run by SKPD with a number of performance indicators 135 , with gains of as much as 83 indicators reach or exceed the target, as many as 15 indicators did not reach the target, but increased compared to the year 2013, and 37 indicators were below target

2) Efforts to create a system of public policy relating to the affairs of the regions in Ciamis in increasing the gains can be made through:

- Increased capacity and capability of human resources Apparatus

- cultural transformation of a paradigm shift in the cultural aspects

\section{REFERENCES}

[1] Thoha, miftah 2000.peran ilmu administrasi public dalam mewujudkan tata keperintahan yang baik, orasi ilmiah, disampaikan pada pembukaan kuliah PPS UGM tahun akademik 2000/2001, 4 september 2000.

[2] Dwiyanto, agus 2015. Administrasi public:desentralisasi, kelembagaan, dan Aparatur Sipil Negara.Yogyakarta: Gadjah Mada University Press

[3] Keban, yeremias T, 2004, enam dimensi strategis administrasi public: konsep, teori dan Isu (edisi pertama), Yogyakarta: gava media.

[4] Nakamura, Robert, T \& frank smallwood (2000) the politics of police implementation, new York: St. martin Prees.

[5] Jones, Charles O, 2000, an introduction to the studi of public policy. Belmont, California: wadsworth, Inc.

[6] Van meter Donald \& Van horn, carl E, 1978, the policy implementation prosess - a conceptual framework, (journal administration and society, vol.04, p 7-16).

[7] Rusli, Budiman, 2015, isu-isu krusial administrasi public kontemporer, Bandung, Mega Rancage Press.

[8] Sasmojo, saswinandi, 2004, Sains, Teknologi, masyarakat dan pembangunan, Bandung, Program Pascasarjana Studi Pembangunan ITB.

[9] Anderson J.E. 1976. Public Policy Making, Holt Rinerhard and Winston, New York 